\title{
IMPLEMENTASI APLIKASI TOKO ONLINE GANGER UNTUK PENDAUR ULANG SAMPAH BERBASIS WEB DI TASIKMALAYA
}

\author{
Andi Nur Rachman ${ }^{1)}$, Cecep Muhamad Sidik Ramdani ${ }^{2)}$, Euis Nur Fitriani Dewi ${ }^{3)}$ \\ Informatika, Fakultas Teknik, Universitas Siliwangi ${ }^{1,2,3)}$ \\ Jl Siliwangi No24, Kota Tasikmalaya, 46115, Indonesia \\ Email: andy.rachman@ unsil.ac.id ${ }^{1)}$, cecepmuhamad@ unsil.ac.id ${ }^{2)}$, euis.nurfitriani@unsil.ac.id ${ }^{3)}$
}

\begin{abstract}
ABSTRAK
Saat ini pada tahun 2018 industri kreatif indonesia sedang berkembang dengan pesat dengan bukti munculnya start up dan perusahaan karya anak bangsa semakin banyak bermunculan seperti halnya Go-Jek, BukaLapak dan lainnya. Masyarakat pun sangat mendukung hal ini, terlihat dari banyaknya pengguna di setiap platform tersebut. Hal ini dapat menyimpulkan bahwa masyarakat Indonesia saat ini lebih memilih fasilitas yang efesien, cepat dan murah. Maka dari itu perusahaan digitat memiliki pasar yang luas di Indonesia. Masalah tersebut seperti masalah ekonomi dan sampah, Garbage Ranger atau disingkat GANGER hadir sebagai aplikasi yang dapat menjadi penghubung jual-beli antar penyedia atau pengelola sampah dan pembisnis daur ulang, menjadi tempat jual-beli antar konsumen dan pembisnis daur ulang, menjadi penyedia informasi pembuatan produk-produk dari sampah dan penyedia informasi harga sampah.
\end{abstract}

Kata kunci: Daur Ulang, Garbage Ranger, Platform.

\begin{abstract}
Currently in 2018 Indonesia's creative industry is growing rapidly with evidence of the emergence of start-ups and companies of the nation's work more and more popping up as well as GoJek, BukaLapak and others. The community is also very supportive of this, seen from the number of users on each of these platforms. This can conclude that the Indonesian people today prefer facilities that are efficient, fast and inexpensive. Therefore the Digitat company has a wide market in Indonesia. These problems such as economic and waste issues, Garbage Ranger or abbreviated as GANGER present as an application that can be a link between buying and selling providers or waste management and recycling business, becoming a place of buying and selling between consumers and recycling businesses, being a provider of information on product manufacturing -products from trash and waste pricing information providers.
\end{abstract}

Keywords: Garbage Ranger, Platform, Recycling. 


\section{PENDAHULUAN}

Indonesia merupakan negara dengan populasi terbanyak ke 4 di dunia dengan jumlah 265 juta lebih dan masih terus bertambah. Melihat jumlah populasi yang begitu besar ini, Indonesia yang dimana masyarakatnya terkenal konsumtif ini pastinya juga memliki volume sampah yang diprediksi pada tahun 2018 dapat mencapai 66,5 Juta Ton. Dimana negara masih lambat dalam menangani pengelolahan sampah ini dari terkendalanya anggaran di pemerintahan daerah, masyarakat membuang sampah tidak pada tempatnya, dan tidak ada tindakan hukum yang jelas bagi pembuang sampah sembarangan.

Masalah sampah ini tidak dapat dibiarkan karena hal ini bisa menjadi sumber suatu masalah seperti terjadinya banjir, polusi tanah, polusi udara, dan dapat menjadi sumber penyakit seperti Demam berdarah. Maka dari itu masalah pengelolahan sampah ini harus benar-benar di benah dan diperbaiki.

Selain masalah sampah ini Indonesia juga terkendala dalam perekonomian rakyatnya. Dimana persentase penduduk miskin di Indonesia mencapai 10,12 persen per September 2017. Dengan penduduk yang mencapai 265 juta, presentasi 10 persen ini terhitung sangatlah banyak. Masalah ekonomi ini terjadi karena disebabkan beberapa faktor seperti lapangan kerja yang tidak seimbang dengan jumlah angkatan kerja, kualitas SDM yang rendah, masyarakat takut menjadi pengusaha dan sifat malas kerja masyarakat yang sudah mengakar.

Mitra BST Cabang Singaparna dan BST Cabang Cikunir berdiri pada tanggal 22 Oktober 2014 dibawah binaan Dinas Tata Ruang dan Pemukiman dan Kantor Lingkungan Hidup, dalam waktu yang relatif tidak lama telah berhasil merekrut 1500-an orang nasabah dengan 13 titik Unit kepengurusan, yang disebut dengan unit usaha berlokasi di wilayah penyanga ibukota kabupaten Tasikmalaya di Kecamatan Singaparna.

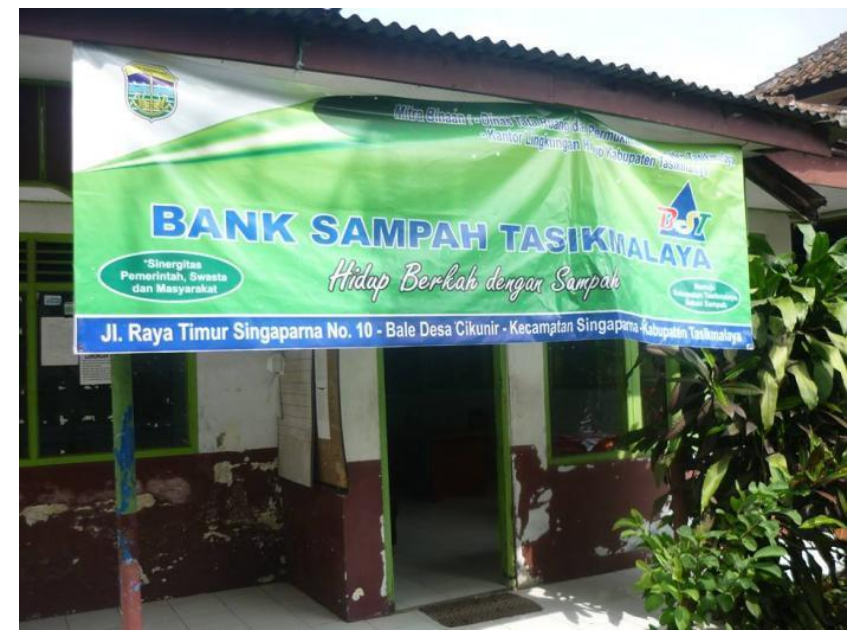

Gambar 1. Kantor Bank sampah Tasikmalaya

Mitra Bank Sampah sudah mempunyai konsep daur ulang sampah dan dipilah serta memiliki manajemen layaknya perbankan tapi yang ditabung bukan uang melainkan sampah. Masyarakat yang menabung yang juga disebut nasabah memiliki buku tabungan dan dapat meminjam uang yang nantinya dikembalikan dengan sampah seharga uang yang dipinjam. Sampah yang ditabung ditimbang dan dihargai dengan sejumlah uang nantinya akan dijual di pabrik yang sudah bekerja sama. 
Menyikapi masalah diatas seperti masalah ekonomi dan sampah, Garbage Ranger atau disingkat GANGER hadir sebagai aplikasi yang dapat menjadi penghubung jual-beli antar penyedia atau pengelola sampah dan pembisnis daur ulang, menjadi tempat jual-beli antar konsumen dan pembisnis daur ulang, menjadi penyedia informasi pembuatan produk-produk dari sampah dan penyedia informasi harga sampah.

\section{Tinjauan Pustaka}

\subsection{Bank Sampah}

Bank Sampah adalah salah satu alternatif meningkatkan kepedulian masyarakat akan lingkungan. Bank sampah merupakan sistem pengelolaan sampah berbasis rumah tangga, system bank sampah ini memiliki beberapa keunggulan selain manfaatnya dibidang kesehatan lingkungan, metode ini juga berfungi untuk memberdayakan masyarakat dengan menyetorkan sampah yang telah dipilah, sehingga masyarakat bisa mendapatkan keuntungan secara ekonomis (Yulia, 2014).

\subsection{Pengertian Sistem Informasi}

Sistem berasal dari bahasa latin (systema) dan bahasa Yunani (sustema) adalah suatu kesatuan yang terdiri dari komponen atau elemen yang dihubungkan bersama untuk memudahkan aliran informasi, materi atau energi untuk mencapai suatu tujuan (Purwanto, dkk, 2012).

Informasi adalah pesan (ucapan atau ekspresi) atau kumpulan pesan yang terdiri dari order sekuens dari simbol, atau makna yang dapat ditafsirkan dari pesan atau kumpulan pesan. Informasi dapat direkam atau ditransmisikan.

Sistem Informasi merupakan kegiatan memanfaatkan teknologi untuk mengumpulkan data yang kemudian diproses menjadi informasi untuk disimpan, digunakan dan disebarkan, jadi sistem informasi adalah suatu sistem yang menyediakan informasi untuk manajemen dalam mengambil keputusan dan juga untuk menjalankan operasional perusahaan, di mana sistem tersebut merupakan kombinasi dari orang-orang, teknologi informasi dan prosedur-prosedur yang terorganisasi.

\subsection{Pengertian Perencanaan Strategis Sistem Informasi}

Perencanaan strategis SI/TI merupakan proses identifikasi portfolio aplikasi SI berbasis komputer yang akan mendukung organisasi dalam pelaksanaan rencana bisnis dan merealisasikan tujuan bisnisnya. Perencanaan strategis SI/TI mempelajari pengaruh SI/TI terhadap kinerja bisnis dan kontribusi bagi organisasi dalam memilih langkah-langkah strategis. Selain itu, perencanaan strategis SI/TI juga menjelaskan berbagai alat, teknik, dan kerangka kerja bagi manajemen untuk menyelaraskan strategi SI/TI dengan strategi bisnis, bahkan mencari kesempatan baru melalui penerapan teknologi yang inovatif (Purwanto, dkk, 2012).

Perencanaan Strategis SI/TI merupakan Pendekatan sistematis untuk menentukan mana yang paling efektif dan efisien berkaitan dengan kepuasan pemenuhan kebutuhan informasi.

Berdasarkan definisi - definisi yang ada, maka dapat disimpulkan definisi dari perencanaan strategi sistem informasi adalah suatu proses analisis secara menyeluruh dan sistematis dalam merumuskan tujuan dan sasaran perusahaan, serta menentukan strategi yang memanfaatkan kelebihan dari sistem informasi dan dukungan teknologi informasi dalam menunjang strategi bisnis dan memberikan keunggulan kepada perusahaan dalam bersaing. 


\subsection{Unified Modelling Language (UML)}

Perkembangan teknik pemrograman berorientasi objek, munculah sebuah standarisasi bahasa pemodelan untuk pembangunan perangkat, lunak yang dibangun dengan menggunakan teknik pemrograman berorientasi objek, yaitu Unified Modeling Language (UML). UML muncul karena adanya kebutuhan pemodelan visual untuk menspesifikasikan, menggambarkan, membangun, dan dokumentasi dari sistem perangkat lunak (Rahmatullah, 2016). UML disebut sebagai bahasa pemodelan bukan metode. Kebanyakan metode minimal terdiri dari: prinsip, bahasa pemodelan dan proses. Bahasa pemodelan (sebagian besar grafik) merupakan notasi dari metode yang digunakan untuk mendesain secara cepat. Bahasa pemodelan merupakan bagian terpenting dari metode. Ini merupakan bagian kunci tertentu untuk komunikasi. UML merupakan bahasa standar untuk penulisan konsep perangkat lunak yang digunakan untuk visualisasi (visualize), spesifikasi (specify), pembentukan (construct) dan pendokumentasian (documentation) alat-alat dari sistem perangkat lunak. Keunggulan menggunakan UML diantaranya:

1. Uniformity, pengembang cukup menggunakan satu metodologi dari tahap analisis hingga perancangan. Memungkinkan merancang komponen antarmuka secara terintegrasi bersama perancangan perangkat lunak dan perancangan struktur data.

2. Understandability, kode yang dihasilkan dapat diorganisasi ke dalam kelas-kelas yang berhubungan dengan masalah sesungguhnya sehingga lebih mudah untuk dipahami.

3. Stability, kode program yang dihasilkan relatif stabil sepanjang waktu, karena mendekati permasalahan yang sesungguhnya.

4. Reusability, dengan metodologi berorientasi objek, dimungkinkan penggunaan ulang kode, sehingga pada akhirnya akan sangat mempercepat waktu pengembangan perangkat lunak (atau sistem informasi).

UML mendefinisikan diagram-diagram sebagai berikut :

1. Use Case Diagram, menggambarkan fungsionalitas yang diharapkan dari sebuah sistem. Penekanannya adalah "apa" yang diperbuat sistem, dan bukan "bagaimana". Sebuah use case merepresentasikan sebuah interaksi antara aktor dengan sistem. Use case merupakan sebuah pekerjaan tertentu, misalnya login ke sistem, meng-create sebuah daftar belanja, dan sebagainya. Seorang atau sebuah aktor adalah sebuah entitas manusia atau mesin yang berinteraksi dengan sistem untuk melakukan pekerjaan-pekerjaan tertentu.

2. Class Diagram, sebuah spesifikasi yang jika diinstansiasi akan menghasilkan sebuah objek dan merupakan inti dari pengembangan dan desain berorientasi objek. Class menggambarkan keadaan (atribut atau properti) suatu sistem, sekaligus menawarkan layanan untuk memanipulasi keadaan tersebut (metode atau fungsi). Class diagram menggambarkan struktur dan deskripsi class, package dan objek beserta hubungan satu sama lain seperti containment, pewarisan, asosiasi, dan lain-lain.

Sequence Diagram, menggambarkan interaksi antar objek di dalam dan di sekitar sistem (termasuk pengguna, display, dan sebagainya) berupa message yang digambarkan terhadap waktu. Sequence diagram terdiri atar dimensi vertikal (waktu) dan dimensi horisontal (objek-objek yang terkait). 


\section{Metodologi Penelitian}

Berdasarkan masalah prioritas mitra di atas, maka pendekatan pelaksanaan pengabdian menggunakan tahapan sebagai berikut:

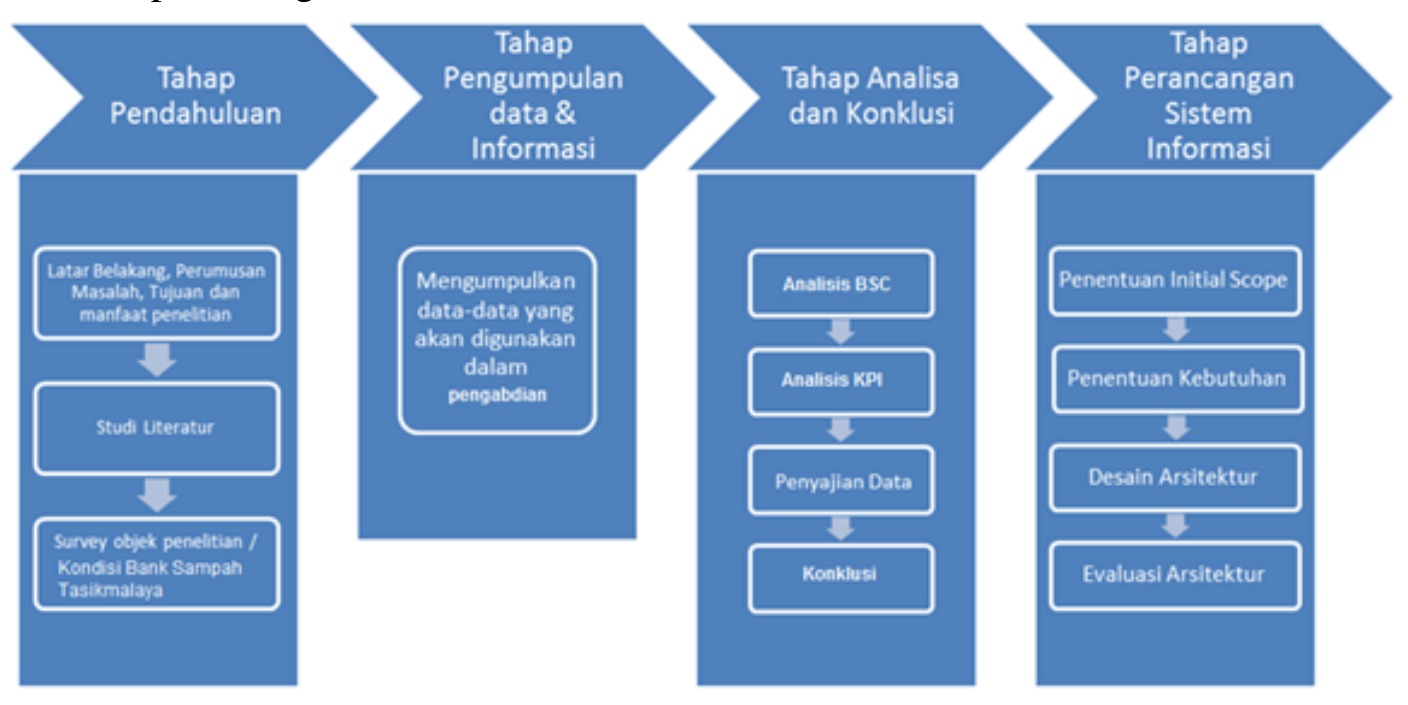

Gambar 2. Tahapan Kegiatan Pengabdian

a) Tahap Pendahuluan. Fase ini telah dilakukan, yaitu merupakan analisis awal (observasi) pada mitra dan mencari solusi dari masalah tersebut. Target dari fase ini memperoleh masalah mitra dan menentukan solusinya.

b) Tahap Pengumpulan Data dan Informasi, yaitu menganalisa dari data yang terkumpul, diambil dan disusun ulang untuk selanjutnya dijadikan masukan untuk tahapan selanjutnya, yaitu analisis BSC (Balanced Score Card) dan KPI (Key Performance Indicator).

c) Tahap Analisa dan Konklusi, fase ini adalah proses pengukuran sejauh mana sistem informasi diperlukan oleh setiap unit usaha, hal ini dapat dilakukan dengan melakukan analisis Balanced Score Card, kemudian selanjutnya dilakukan analisis Key Performance Indicator untuk mengetahui prioritas penerapan sistem informasi pada setiap proses bisnis yang dilakukan.

d) Tahap Perancangan Sistem Informasi. Fase ini dimulai dengan pembuatan system informasi dengan masukan yang telah disesuaikan dengan kebutuhan, dengan rekayasa perangkat lunak menggunakan konsep SDLC (Sofware Development Life Cycle). Kemudian dalam penggunaan sistem informasi ini dilakukan pendampingan dan pelatihan dari tim pengusul.

\section{Hasil dan Pembahasan}

Aplikasi Toko Online Untuk Pendaur Ulang Sampah sebagai Sistem Informasi Bank Sampah yang memiliki fungsi utama sebagai kontrol terhadap Mitra Bank Sampah yang dimilikinya, sistem informasi ini terintegrasi dalam hal pelaporan dan pelaksanaan proses bisnis dari setiap unit usaha.

Tahapan perancangan sistem meliputi perancangan Flowchart Sistem, Unified Modeling Language dan User Interface aplikasi. Tools yang digunakan meliputi Corel Draw, Adobe Ilustrator dan DreamWaver.

\subsection{Unified Modeling Language}

Berikut merupakan contoh Unified Modeling Language (UML) berupa Use Case Diagram yang menggambarkan kinerja sistem dari aplikasi. 


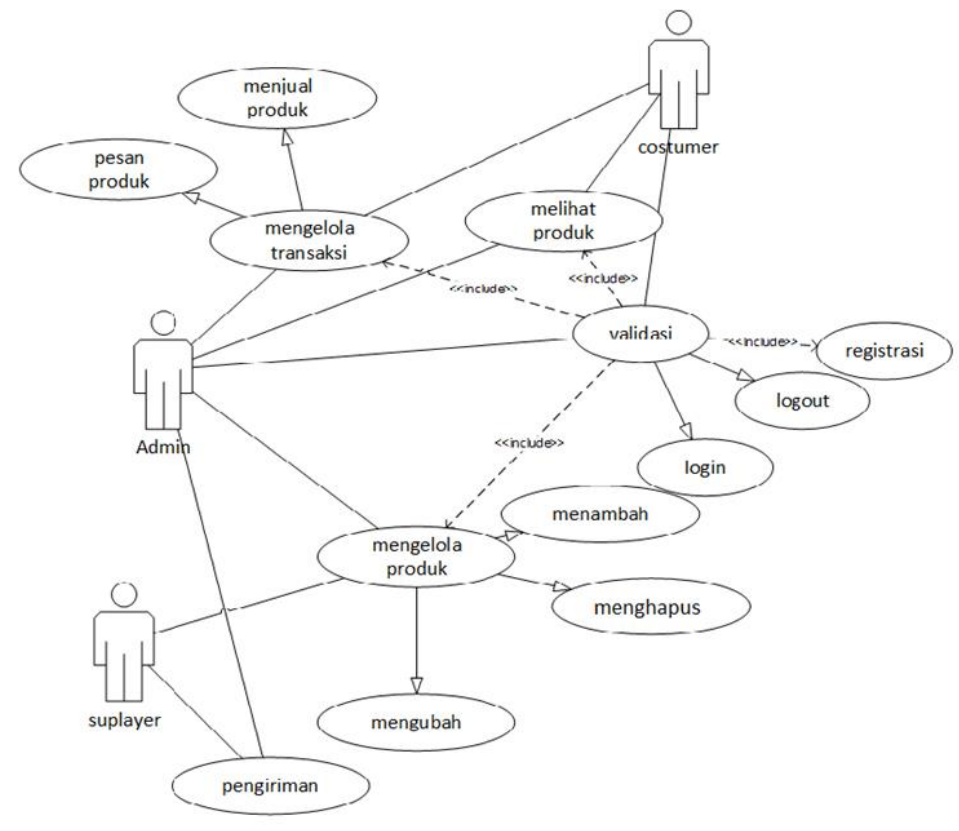

Gambar 3. UML Use Case Diagram.

Tabel 1. Aksi Aktor dan Respon Sistem Melakukan Transaksi

\begin{tabular}{ll}
\hline \multicolumn{1}{c}{ Aksi Aktor } & \multicolumn{1}{c}{ Respon Sistem } \\
\hline $\begin{array}{l}\text { 1. Aktor masuk ke form transaksi setelah } \\
\text { mendapatkan produk }\end{array}$ & $\begin{array}{l}\text { 2. Sistem menampilkan total harga barang yang } \\
\text { telah dipesan Customer }\end{array}$ \\
& $\begin{array}{l}\text { 3. Sistem memberikan opsi pembayaran dan no } \\
\text { rekening pembayaran }\end{array}$ \\
$\begin{array}{ll}\text { 4. Aktor mendapatkan no rekening dari } & \\
\begin{array}{l}\text { Sistem } \\
\text { Aktor memverifikasi pembayaran setelah } \\
\text { melakukan transfer }\end{array} & \text { 6. Sistem memberikan konfirmasi pembayaran } \\
\text { sukses }\end{array}$ \\
\hline
\end{tabular}

Tabel 2. Skenario Mengelola Produk

\begin{tabular}{ll}
\hline \multicolumn{1}{c}{ Use Case } & \multicolumn{1}{c}{ Mengelola Produk } \\
\hline Description & Aktor dapat mengelola produk yang akan dijual, yakni menambahkan, \\
& mengubah atau mengurangi produk \\
Actor \& Interface & Aktor : Supplier \& Admin \\
Pre-condition & Supplier belum mengelola produk yang akan dijual \\
Basic Flow & - Supplier menambahkan produk yang akan dijual \\
& - Supplier mengurangi produk yang akan dijual \\
& - Supplier mengubah produ yang akan dijual \\
& - Admin mengontrol mengenai aktivitas yang dilakukan supplier, baik itu \\
& mengubah, mengurangi atau menambahkan produk. \\
Post-condition & Supplier telah menambahkan produk ataupun mengurangi dan mengubah \\
& produk \\
Alternatif(s) Flow & Supplier tidak mengelola produk sampah \\
\hline
\end{tabular}


Tabel 3. Aksi Aktor dan Respon Sistem Melakukan Pengelolaan Produk

\section{Aksi Aktor}

2. Aktor melakukan pengelolaan produk yang akan dijual dari opsi yang telah diberikan oleh sistem

\section{Respon Sistem}

1. Sistem memberikan opsi pengelolaan produk, yakni : menambahkan, mengubah atau mengurangi produk

3. Sistem memperbarui pengelolaan produk yang akan dijual Supplier

Tabel 4. Skenario Pengiriman Produk

\begin{tabular}{ll}
\hline \multicolumn{1}{c}{ Use Case } & \multicolumn{1}{c}{ Pengiriman } \\
\hline Description & Aktor dapat mengirim produk yang akan dijual di Ganger \\
Actor \& Interface & Aktor : Supplier \& Admin \\
Pre-condition & Supplier belum mengirim produk yang akan dijual \\
Basic Flow & - Supplier mengitim produk yang akan dijual \\
& - Admin mengontrol mengenai aktivitas yang dilakukan supplier, yakni \\
Post-condition & pengiriman produk yang akan dijual supplier \\
Alternatif(s) Flow & Supplier telah mengirim produk yang telah dijual \\
\hline
\end{tabular}

\subsection{Class Diagram}

Berikut merupakan class diagram yang menggambarkan data base dalam aplikasi.

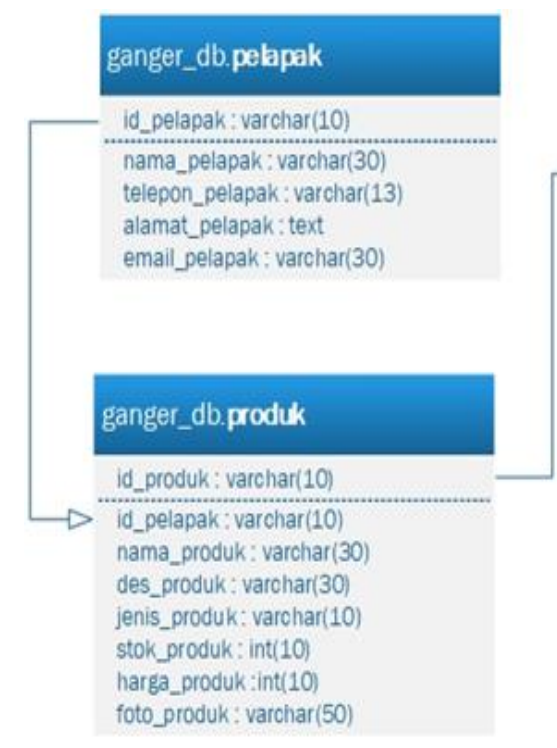

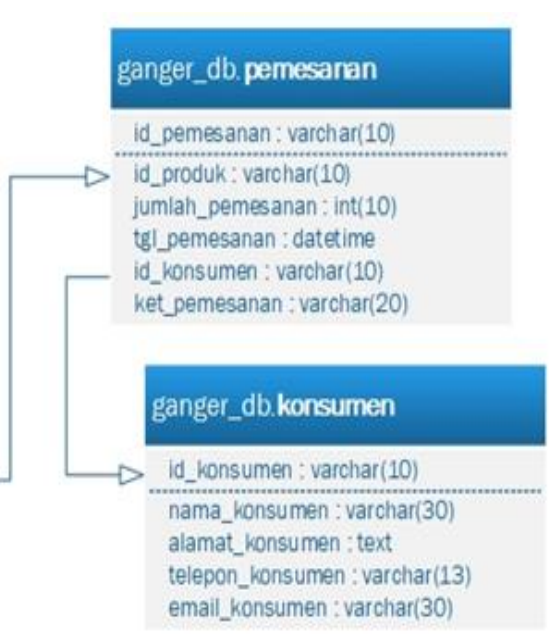

Gambar 4. Class Diagram.

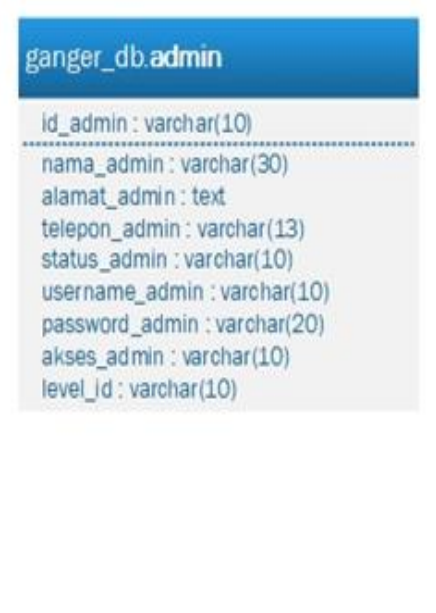

\subsection{Pembahasan dan Evaluasi}

Alur aplikasi web GANGER adalah penjual produk dan penjual sampah akan menginputkan data barang (sampah atau produk daur ulang) yang akan dijual. Sistem akan menyimpan data tersebut ke database sehingga nantinya dapat ditampilkan di web sehingga pembeli dapat memilih dan mencari barang yang akan dibeli. Pembeli membeli barang dan melakukan pembayaran ke rekening GANGER yang dimana uang akan diteruskan ke penjual ketika ada konfirmasi penerimaan barang dari pembeli. Penjual akan menerima notifikasi pemesanan dari pembeli dan 
penjual melakukan pengiriman dengan setelahnya penjual memasukan no resi pengiriman ke sistem sehingga pembeli dapat men-tracking pesanannya.

Aplikasi GANGER merupakan aplikasi penyedia layanan jual-beli khusus sampah dan barang bekas serta memberikan informasi seputar sampah dan daur ulang sehingga para pendaur ulang dan pengepul atau pengelola sampah dapat dengan mudah mendapatkan konsumen.

\section{Daftar Pustaka}

Malia, Indiana. (2018). Volume Sampah 2018 Diprediksi Mencapai 66,5 Juta Ton!. Dipetik November 12, 2018, dari IDNTimes: https://www.idntimes.com/news/indonesia/ indianamalia/volume-sampah-2018-diprediksi-mencapai-665-juta-ton-1

Wikipedia. (2018). Daftar Negara menurut jumlah penduduk. Dipetik pada November 12, 2018, dari Wikipedia: https://id.wikipedia.org/wiki/Daftar_negara_menurut_jumlah_penduduk

BPS. (2018). Persentase Penduduk Miskin September 2017 Mencapai 10,12 Persen. Dipetik November 12, 2018, dari Badan Pusat Statistik: https://www.bps.go.id/pressrelease/2018/ 01/02/1413/persentase-penduduk-miskin-september-2017-mencapai-10-12-persen.html

KOMINFO. (2014). Pengguna Internet Indonesia Nomor Enam Dunia. Dipetik November 12, 2018, dari Kementrian Komunikasi Dan Informatika Republik Indonesia: https://kominfo.go.id/content/detail/4286/pengguna-internet-indonesia-nomor-enamdunia/0/ sorotan_media

Arvi, Kodrat, Iman. (2016). tidak diketahui. Perancangan Aplikasi Toko Online "XO-Liciois" Berbasis Mobile Web Pada Sistem Operasi Android. Hal 3-7.

Rahmatullah, Aditya. (2016). Belajar Unified Modeling Language (UML) - Pengenalan. CodePolitan: https://www.codepolitan.com/unified-modeling-language-uml

Purwanto, Irwan. Fatimah, Dini Destiani Siti. Partono. (2012). Perancangan Sistem Informasi Transaksi Tabungan Bank Sampah. Journal STT Garut. Vol. 9.

Ciptani, Monika Kussetya. (2000). Balanced Scorecard Sebagai Pengukuran Kinerja Masa Depan. Jurnal Akuntansi \& Keuangan Vol 2, No. 1. Mei 2000.

Luis Suwardi, wibowo A. Prima. (2007). Step by Step in Cascading Balanced Scorecard to Funcitional Scorecard. Jakarta: Gramedia Pustaka Utama Sari, Indah Permata.(2013). Sepuluh langkah Cascading Balanced Scorecard. http://indahpermata6.blogspot.com/2013/04/ sepuluh-langkah-cascading balanced.html, 03 Februari 2015.

Sunarto, Agus dan Zainal. (2007). Model Perencanaan strategis sistem informasi pada industry penyiaran televisi dengan pendekatan Blue Ocean Strategy dan Balanced Score Card, Jurnal Sistem Informasi. MTI UI. Vol 3. No. 2.

Tanone Radius, Manongga Danny dan Tambotoh Johan. (2013). Sistem Pemantau Kinerja Berbasis Balanced Scorecard. Jurnal Dokumentasi dan informasi. Bandung. Desember 2013.

Yulia, Reiza Fitri. (2014). Makalah Bank Sampah Untuk Menghasilkan Uang. http://reizacullen777.blogspot.com/2014/11/makalah-bank-sampah-untuk-menghasilkan.html, 03 Februari 2015. 